\title{
Towards a more complete quantification of the global carbon cycle
}

\author{
Miko U. F. Kirschbaum ${ }^{1}$, Guang Zeng ${ }^{2}$, Fabiano Ximenes ${ }^{3}$, Donna L. Giltrap ${ }^{1}$, and John R. Zeldis ${ }^{4}$ \\ ${ }^{1}$ Landcare Research - Manaaki Whenua, Private Bag 11052, Palmerston North 4442, New Zealand \\ ${ }^{2}$ National Institute of Water \& Atmospheric Research, Private Bag 14901, Wellington 6021, New Zealand \\ ${ }^{3}$ Forest Science Unit, New South Wales Department of Primary Industries, Locked Bag 5123, \\ Parramatta, New South Wales 2150, Australia \\ ${ }^{4}$ National Institute of Water \& Atmospheric Research, PO Box 8602, Christchurch 8011, New Zealand
}

Correspondence: Miko U. F. Kirschbaum (kirschbaumm@landcareresearch.co.nz)

Received: 3 October 2018 - Discussion started: 1 November 2018

Revised: 17 January 2019 - Accepted: 18 January 2019 - Published: 14 February 2019

\begin{abstract}
The main components of global carbon budget calculations are the emissions from burning fossil fuels, cement production, and net land-use change, partly balanced by ocean $\mathrm{CO}_{2}$ uptake and $\mathrm{CO}_{2}$ increase in the atmosphere. The difference between these terms is referred to as the residual sink, assumed to correspond to increasing carbon storage in the terrestrial biosphere through physiological plant responses to changing conditions $\left(\Delta B_{\text {phys }}\right)$. It is often used to constrain carbon exchange in global earth-system models. More broadly, it guides expectations of autonomous changes in global carbon stocks in response to climatic changes, including increasing $\mathrm{CO}_{2}$, that may add to, or subtract from, anthropogenic $\mathrm{CO}_{2}$ emissions.

However, a budget with only these terms omits some important additional fluxes that are needed to correctly infer $\Delta B_{\text {phys. }}$ They are cement carbonation and fluxes into increasing pools of plastic, bitumen, harvested-wood products, and landfill deposition after disposal of these products, and carbon fluxes to the oceans via wind erosion and non- $\mathrm{CO}_{2}$ fluxes of the intermediate breakdown products of methane and other volatile organic compounds. While the global budget includes river transport of dissolved inorganic carbon, it omits river transport of dissolved and particulate organic carbon, and the deposition of carbon in inland water bodies.

Each one of these terms is relatively small, but together they can constitute important additional fluxes that would significantly reduce the size of the inferred $\Delta B_{\text {phys. }}$. We estimate here that inclusion of these fluxes would reduce $\Delta B_{\text {phys }}$ from the currently reported $3.6 \mathrm{GtC} \mathrm{yr}^{-1}$ down to about $2.1 \mathrm{GtC} \mathrm{yr}^{-1}$ (excluding losses from land-use change). The implicit reduction in the size of $\Delta B_{\text {phys }}$ has important
\end{abstract}

implications for the inferred magnitude of current-day biospheric net carbon uptake and the consequent potential of future biospheric feedbacks to amplify or negate net anthropogenic $\mathrm{CO}_{2}$ emissions.

\section{Introduction}

In its summarised form, the global carbon cycle is usually expressed in the form of six main fluxes (Le Quéré et al., 2018; Fig. 1). Carbon is added to the atmosphere by the burning of fossil fuels $\left(9.0 \mathrm{GtC} \mathrm{yr}^{-1}\right)$, cement production $\left(0.4 \mathrm{GtC} \mathrm{yr}^{-1}\right)$, and ongoing deforestation, mainly in the tropics $\left(1.3 \mathrm{GtC} \mathrm{yr}^{-1}\right)$. Some fossil fuels $\left(0.4 \mathrm{GtC} \mathrm{yr}^{-1}\right)$ are also utilised for the manufacture of other products, like plastics, or are incompletely combusted and thus do not directly emit $\mathrm{CO}_{2}$ to the atmosphere. The atmospheric $\mathrm{CO}_{2}$ concentration has increased to over $400 \mathrm{ppm}$ through annual net additions of about $4.7 \mathrm{GtC} \mathrm{yr}^{-1}$, whereas the oceans overall are still close to their pre-industrial effective equilibrium concentration of $280 \mathrm{ppm}$. This difference constitutes a driving force for ocean $\mathrm{CO}_{2}$ uptake, estimated at $2.4 \mathrm{GtC} \mathrm{yr}^{-1}$ ( $\mathrm{Le}$ Quéré et al., 2018).

Summing these various fluxes results in an imbalance of $3.6 \mathrm{GtC} \mathrm{yr}^{-1}$, often referred to as the "residual sink". This flux cannot be directly and independently estimated but is derived as the residual remaining after estimation of the other terms. In the most recent budget, this has been separated into an estimated "land sink", based on terrestrial biosphere models, and a remaining "budget imbalance" (Le Quéré et al., 2018). 


\section{7-2016}

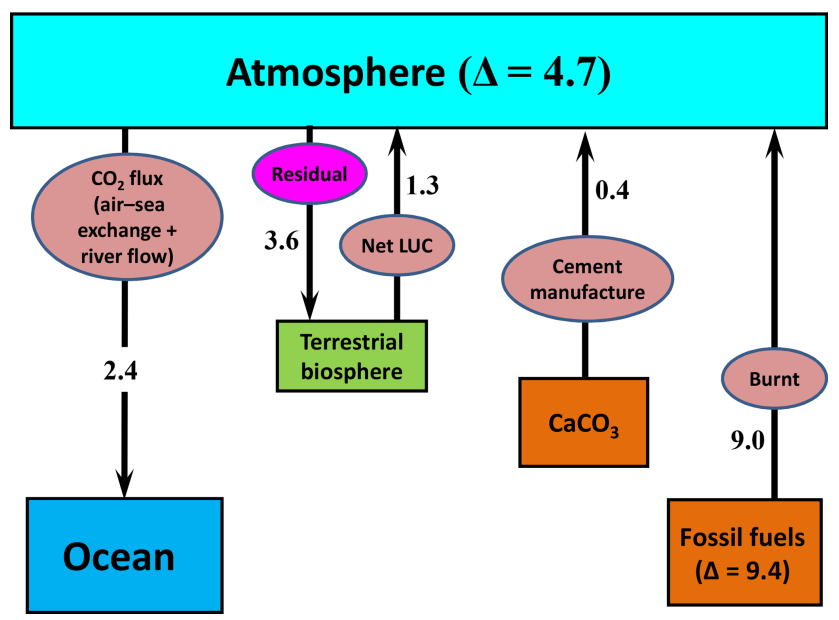

Figure 1. The main components of the global carbon cycle for the 2007-2016 period (after Le Quéré et al., 2018). Annually, $9.4 \mathrm{GtC} \mathrm{yr}^{-1}$ of fossil fuels were used of which $0.4 \mathrm{GtC} \mathrm{yr}^{-1}$ were not oxidised but used for manufacturing secondary products, like plastics, or incompletely combusted so that only $9.0 \mathrm{GtC} \mathrm{yr}^{-1}$ were released to the atmosphere. The ocean flux consists of estimated air-ocean $\mathrm{CO}_{2}$ exchange plus river flux of inorganic $\mathrm{CO}_{2}$.

The size of the residual sink is often implicitly or explicitly equated with carbon uptake by the terrestrial biosphere (e.g. Ciais et al., 2013; Sitch et al., 2015; Arneth et al., 2017;

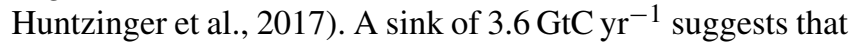
one-third of anthropogenic emissions might be balanced by biospheric carbon uptake and storage. The size of this flux is even more important for future trends in biospheric uptake that could provide an important positive or negative feedback for atmospheric $\mathrm{CO}_{2}$ changes (Cramer et al., 2001; Jones et al., 2013). If the magnitude of terrestrial uptake is over- or underestimated, it would lead to incorrect inference of the strength of future feedback processes between the terrestrial biosphere and the earth's net carbon budget.

However, in the global carbon budget as presented in Fig. 1, several important fluxes have been omitted. In the present work, we aim to provide a quantification of these additional terms based on values found in the existing literature or derived in the current work, and thereby more completely quantify the global carbon cycle. In addition, we estimate the actual increase in carbon stored in the terrestrial biosphere, $\Delta B_{\text {act }}$, by explicitly accounting for the carbon flux into additional carbon-storage pools or through pathways not previously included in global budget calculations. We also estimate the net change in carbon stored in the terrestrial biosphere, $\Delta B_{\text {phys }}$, to refer to the change in stored carbon through physiological plant responses but excluding the effects of land-use change (LUC).

Hence, the present work aims to quantify these additional terms:
1. Net increases in the pools of harvested-wood products, plastic, bitumen, rubber, leather, and textiles while they are in service;

2. Net increases of carbon in anaerobic landfills after subsequent disposal of these products;

3. The carbonation of previously manufactured cement products;

4. River transport from the land to the oceans as dissolved or particulate organic carbon (DOC or POC);

5. Carbon deposition in inland water bodies;

6. Transfer of carbon from the land to the oceans via aeolian transport either attached to mineral dust or as charcoal;

7. Fluxes of non- $\mathrm{CO}_{2}$ carbonaceous gases, principally methane and NMVOCs (non-methane volatile organic compounds), and their intermediate breakdown products.

Of these, $\mathrm{CO}_{2}$ fluxes associated with cement carbonation (Xi et al., 2016) and carbon deposition in fresh-water bodies (e.g. Regnier et al., 2013) constitute obvious fluxes from the atmosphere into relevant storage pools that have not previously been included in global budgets. There is also a sizeable net flux into the pool of harvested-wood products (Lauk et al., 2012). This flux has already been included in net land-use change calculations (Le Quéré et al., 2018), but in the interest of transparency it would be preferable if that flux was quantified more explicitly.

Net carbon fluxes into the pools of plastic and bitumen and subsequently into anaerobic landfills have also been included indirectly by accounting for only an assumed fraction of fossil-fuel carbon being oxidised (e.g. Marland and Rotty, 1984; Le Quéré et al., 2018). A small fraction of fossil fuels is used for manufactured products, such as plastic and bitumen, and of the fossil fuels that are burnt, another small fraction is only incompletely combusted leading to less than $100 \%$ being converted to $\mathrm{CO}_{2}$ (Marland and Rotty, 1984). Based on these considerations, Marland and Rotty (1984) estimated oxidation fractions of $98 \%, 91.8 \%$, and $98.2 \%$ for the utilisation of gas, liquid, and solid fuels, respectively. These terms are then applied to fossil-fuel production data to derive fossil-fuel-based $\mathrm{CO}_{2}$ emission rates (e.g. Andres et al., 2012). In the interests of greater transparency, it would be desirable, however, if fluxes through these key product pathways were more explicitly accounted for and reported in future global emission budgets.

Carbon transport to the oceans through river transport (Regnier et al., 2013), aeolian fluxes (e.g. Romankevich et al., 2009), or gas fluxes by carbonaceous compounds other than $\mathrm{CO}_{2}$ all constitute additional carbon fluxes from the land to the oceans. These fluxes are only incompletely accounted 


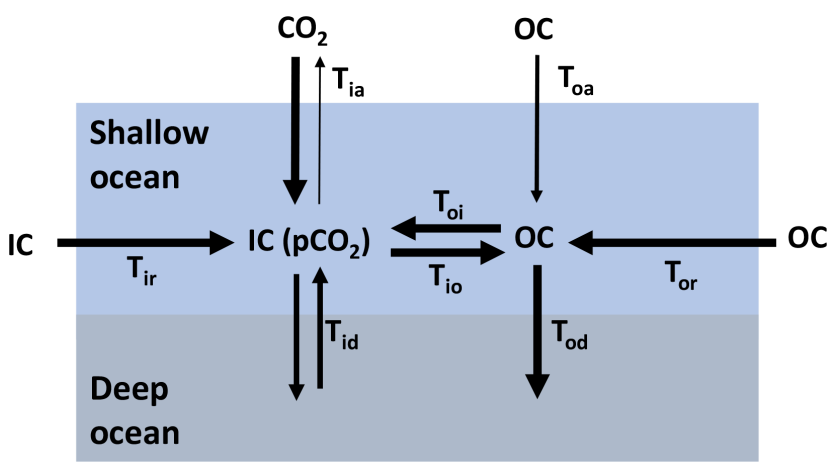

Figure 2. Illustration of the key carbon fluxes from the atmosphere to the deep oceans, with subscripts "i" and "o"; referring to inorganic and organic forms of carbon, respectively. $T_{\mathrm{ia}}$ and $T_{\mathrm{oa}}$ are exchanges with the atmosphere, $T_{\mathrm{ir}}$ and $T_{\mathrm{or}}$ are river transport, $T_{\mathrm{io}}$ and $T_{\mathrm{oi}}$ are the inter-conversions between organic and inorganic forms in the ocean, and $T_{\mathrm{id}}$ and $T_{\mathrm{od}}$ are the transfers from shallow to deep oceans.

for in the standard quantification of the global carbon cycle, and a more complete quantification is given below. The significance of the different terms in land-ocean exchange are discussed in the next section.

\section{Ocean exchange}

In deriving the global carbon budget, Le Quéré et al. (2018) used estimates of air-ocean $\mathrm{CO}_{2}$ exchange rates $\left(T_{\mathrm{ia}}\right.$ in Fig. 2) and added the transport of inorganic carbon via river transport $\left(T_{\text {ir }}\right.$, Fig. 2$)$ with the aim of describing the anthropogenic carbon budget (Jacobson et al., 2007; Le Quéré et al., 2018). However, this omits other important transport pathways as illustrated in Fig. 2. The ultimate key fluxes are the net transport of carbon from the shallow to the deep ocean (or to ocean-floor deposition in shallow seas) as either inorganic $\mathrm{CO}_{2}\left(\mathrm{H}_{2} \mathrm{CO}_{3}, \mathrm{HCO}_{3}^{-}, \mathrm{CO}_{3}^{2-}\right)$, including solid $\mathrm{CaCO}_{3}$, or in any soluble or particulate organic form. Hence, the relevant total carbon transfer, $T_{\mathrm{c}}$, can be described as $T_{\mathrm{c}}=T_{\mathrm{id}}+T_{\mathrm{od}}$ where $T_{\mathrm{id}}$ and $T_{\mathrm{od}}$ are the net carbon transfers to the deep ocean of inorganic and organic carbon, respectively. The shallow ocean is too small for significant carbon storage, but the deep ocean has a large carbon-storage capacity. The shallow ocean is important, however, as the interface between the ocean and the atmosphere and where $p \mathrm{CO}_{2}$ measurements are taken for the estimation of net $\mathrm{CO}_{2}$ exchange between the atmosphere and the shallow ocean.

In the ocean, organic and inorganic forms of carbon continuously interchange. Inorganic carbon is fixed and converted into organic forms by photosynthetic organisms. As these organisms die or are eaten by larger organisms, carbon is respired in inorganic form. The sizes of these conversion fluxes are not important in the present context, as carbon can ultimately be transferred to depth in either organic or inor- ganic form. The net flux of inorganic carbon from the deep ocean may even be negative, with net carbon transfer to depth reliant on organic carbon transfer.

As transfers $T_{\mathrm{id}}$ and $T_{\mathrm{od}}$ are difficult to measure directly, the flux $T_{\mathrm{c}}$ is normally approximated as $T_{\mathrm{c}}=T_{\mathrm{ia}}+T_{\mathrm{ir}}$ while the fluxes of organic carbon from atmospheric transfer or river transport, $T_{\mathrm{oa}}$ and $T_{\mathrm{or}}$, are ignored and omitted from the estimated global fluxes. Instead, we propose that the more appropriate total flux should be calculated as $T_{\mathrm{c}}=T_{\mathrm{ia}}+T_{\mathrm{ir}}+$ $T_{\mathrm{oa}}+T_{\mathrm{or}}$. Below, we quantify the different fluxes of organic carbon to the oceans to complete the overall sums.

\section{Calculation details}

For comparison between the residual sink and estimates of carbon exchange of the land biosphere, we used the data given by Le Quéré et al. (2018) as land sink and budget imbalance for different years. Previous carbon budgets (e.g. Le Quéré et al., 2016) provided numbers denoted as residual sink activity. In the 2018 budget, this has been disaggregated into a land sink, estimated from biosphere models, and a budget imbalance term (Le Quéré et al., 2018). The sum of these two terms equates to the previously given residual sink, $S_{\mathrm{r}}$.

Changes in terrestrial $\mathrm{C}$ stocks were calculated as

$$
\begin{aligned}
& \Delta B_{\text {phys }}=S_{\mathrm{r}}-R_{\mathrm{d}}-R_{\mathrm{p}}-R_{\mathrm{i}}-D-V-C-\Delta P \\
& \quad-\Delta B-\Delta L+N \\
& \Delta B_{\text {act }}=\Delta B_{\text {phys }}+\text { LUC },
\end{aligned}
$$

where $R_{\mathrm{d}}$ is river transport as DOC; $R_{\mathrm{p}}$ is river transport as POC; $R_{\mathrm{i}}$ is carbon deposition in inland waterways; $D$ is carbon transport to the oceans as aeolian dust deposits; $V$ is transfer from volatile intermediate oxidation products of methane and NMVOCs; $C$ is carbon storage in cement carbonation; $\Delta P, \Delta B$, and $\Delta L$ are the changes in carbon stored in plastics, bitumen, and landfills, respectively; and $N$ is the non-oxidised fraction of fossil consumption that has been implicitly included in previous budgets. The terms $\Delta P, \Delta B$, and $\Delta L$ therefore largely cancel out the term $N$, but the calculations are made more explicit here.

The term $\Delta B_{\text {act }}$ refers to the actual change in total terrestrial biosphere carbon stocks, including changes due to land-use change, and $\Delta B_{\text {phys }}$ refers to biospheric carbonstock changes due to physiological and age-class effects, but excluding land-use change. LUC is the carbon-stock change due to land-use change with negative numbers denoting net losses to the atmosphere. Of these various components, no temporal trends were available for $R_{\mathrm{d}}, R_{\mathrm{p}}, R_{\mathrm{i}}$, $D$ or $V$, but temporal patterns could be included for $\Delta P$, $\Delta B, C, \Delta L$, and $N$ based on the work of Lauk et al. (2012) and $\mathrm{Xi}$ et al. (2016) and calculated, following Marland and Rotty (1984), as

$N=F(0.02 g+0.082 l+0.018 s)$, 
where $F$ is total fossil-fuel consumption and $g, l$ and $s$ are the percentages of gas, liquid, and solid fuel, respectively, in the global mix of fossil fuels, estimated as constant percentages of $17.0 \%, 41.8 \%$, and $41.2 \%$, respectively; the constants in Eq. (3) have been taken from Marland and Rotty (1984).

\section{Wood products, plastics, bitumen, and cement carbonation}

For harvested-wood products, plastic, and bitumen in service by human societies, the relevant quantity in the present context is the net increase in the size of these pools. At the end of their service lives, plastic and harvested-wood products, especially paper products, may be reused, recycled, or disposed of either by incineration or disposal in landfills. If they are incinerated in waste-to-energy facilities, $\mathrm{CO}_{2}$ is released to the atmosphere immediately, and if they are reused or recycled, the products re-enter the "in-service" pool. Alternatively, these products may be deposited in landfills in countries that use landfills as part of their waste management strategies, which will be discussed in the next section.

For harvested-wood products in service, net increases in carbon stocks primarily correspond to the pool of long-lived structural wood products, such as housing frames. Paper products, on the other hand, tend to have short service lives and do not build up to sizeable pools even though fluxes through these pools can be substantial. This can include multiple passes through the active-service pool because paper products may be recycled repeatedly before eventual disposal. Le Quéré et al. (2018) included a simple term in the calculations of net land-use change that accounted for harvested-wood products. They assumed that a fraction of the wood lost through land-use change was not directly lost as $\mathrm{CO}_{2}$ to the atmosphere but retained in harvested-wood products. However, we believe that a more explicit representation of this pool, as provided through the work of Winjum et al. (1998) and Lauk et al. (2012), would be desirable for greater transparency.

The socio-economic models of Kayo et al. (2015) and Brunet-Navarro et al. (2016) have shown that in poorer societies, wood use per person increases with increasing wealth (quantified as gross domestic product, GDP, per capita, $\mathrm{cp}^{-1}$ ). However, that relationship saturates at intermediate values of GDP cp ${ }^{-1}$ and even becomes negative for the wealthiest societies. Lauk et al. (2012) estimated that humans own on average approximately $1 \mathrm{tC} \mathrm{cp}-1$ of harvested-wood products. If that value is remaining constant over time, one could assume an annual increase in the global pool by about $80 \mathrm{MtC} \mathrm{yr}^{-1}$ purely driven by global population growth. If wood use per person is also increasing, as shown by Kayo et al. (2015), it would result in an increase in the global harvested-wood-products pool by more than $80 \mathrm{MtC} \mathrm{yr}^{-1}$. Winjum et al. (1998) and Lauk et al. (2012) estimated changes in the harvested-wood-products pool from analy-

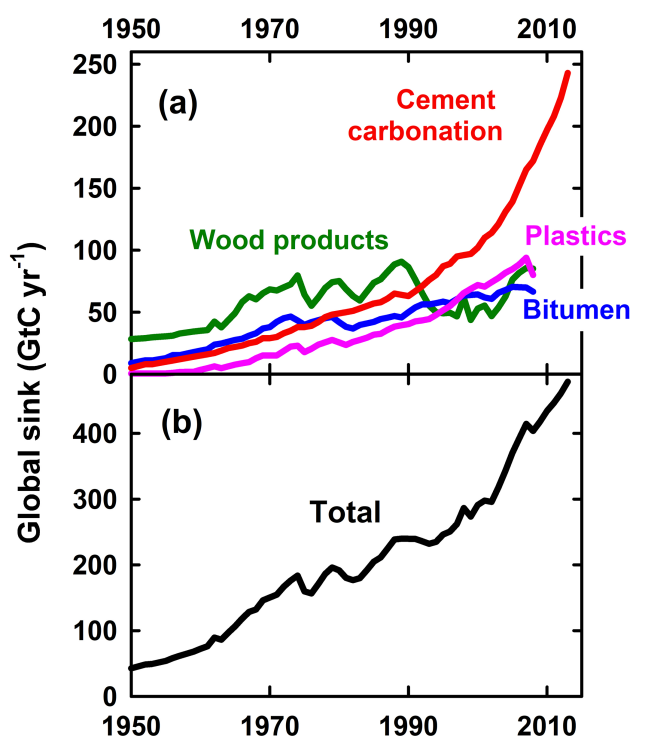

Figure 3. Estimated net fluxes of carbon into the pools of harvestedwood products, plastics, bitumen, and cement carbonation since 1950 (a) and their combined total (b). Based on data given in Lauk et al. (2012) and Xi et al. (2016).

sis of wood-production statistics and assumption of product longevities. Winjum et al. (1998) estimated an annual increase of about $140 \mathrm{MtC} \mathrm{yr}^{-1}$, while Lauk et al. (2012) provided a slightly smaller estimate of recent increases of just

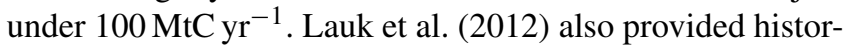
ical estimates over the 20th century (Fig. 3a).

However, for most countries and wood-product categories (paper, wood panels, and sawn wood), there are no reliable service life factors. Global analyses, therefore, have had to rely on the use of generic factors, such as IPCC default Tier 2 half-lives (IPCC, 2014). Lauk et al. (2012) considered the need to use these generic factors as the primary cause of the large uncertainties in their estimated carbon fluxes into harvested-wood-product pools. Lauk et al. (2012) also estimated fluxes into the pools of bitumen, used mainly for road construction, and plastics (Fig. 3a). Fluxes started from very low values before 1950 but have increased steadily and are now similar to fluxes into the pool of harvested-wood products.

In the case of cement carbonation, the flux is associated with the degeneration of previously manufactured cement. Cement manufacture is essentially the calcination of $\mathrm{CaCO}_{3}$ into $\mathrm{CaO}$ under high temperature. The resultant $\mathrm{CO}_{2}$ release is included in global carbon budgets (Andrew, 2018) and accounts for about $4 \%$ of total anthropogenic $\mathrm{CO}_{2}$ emissions (Le Quéré et al., 2018; Fig. 1). When cement is subsequently exposed to rain and natural $\mathrm{CO}_{2}$ concentrations, the process is reversed, and $\mathrm{CO}_{2}$ is reabsorbed, replacing oxygen bound to calcium (Xi et al., 2016). This causes the gradual degradation of cement, with the rate of degradation determined by the slow diffusion of $\mathrm{CO}_{2}$ into any cement products. 
All cement is subject to that kind of degradation, with its rate decreasing with the thickness of the cement layer. Thinner layers of mortar therefore degrade faster than more solid concrete structures. When a building is demolished, cement carbonation tends to increase as cement becomes fragmented, thereby opening new surfaces that assist the diffusional penetration of $\mathrm{CO}_{2}$. The rate of cement carbonation can, therefore, be approximated as being proportional to total cumulative past cement production. Hence, global carbonation rates were likely to have been low in the 1950s, then increased gradually to the 1990s (Fig. 3a), with much more substantial increases since then. Using statistics of historical cement production in different categories, $\mathrm{Xi}$ et al. (2016) estimated recent uptake rates through carbonation of about $250 \mathrm{MtC} \mathrm{yr}^{-1}$, with uptake rates expected to continue increasing into the future.

The combined flux from these four fluxes (cement carbonation and increasing pools of harvested-wood products, plastic, and bitumen) was estimated to have been less than $50 \mathrm{MtC} \mathrm{yr}^{-1}$ in 1950 but increased steadily to about $300 \mathrm{MtC} \mathrm{yr}^{-1}$ by the year 2000 (Fig. 3b). The rate of uptake has increased more sharply since then, driven mainly by increasing cement carbonation, and is estimated to have reached about $450 \mathrm{MtC} \mathrm{yr}^{-1}$ by 2010 (Fig. 3b).

\section{Landfill storage}

At the end of their service lives, products may be disposed of in landfills, where conditions may be aerobic, semi-aerobic or anaerobic depending on their management (IPCC, 2006). If materials are kept under anaerobic conditions, their effective storage life can be extended substantially, with very slow decomposition and resultant carbon loss (Wang et al., 2011, 2015; Ximenes et al., 2015, 2018, 2019).

Wood and plastics are particularly persistent after disposal unless they are incinerated. Bitumen is not usually disposed of, but, when roads are renewed, old bitumen is typically recycled, with only minor losses (Lauk et al., 2012). Textiles, rubber, and leather make additional minor contributions to total landfill carbon stocks. With all categories added together, anaerobic landfills can thus store large amounts of carbon.

Lauk et al. (2012) estimated total annual disposal rates of various key products (Fig. 4), estimated at nearly $500 \mathrm{MtC} \mathrm{yr}^{-1}$. While Fig. 4 clearly shows the historical pattern of product disposal, it does not indicate what quantities of products are disposed of in anaerobic landfills. To the best of our knowledge, there have been no prior estimates of global net carbon stock changes in landfills. We have therefore attempted to provide a first global estimate of waste disposal in anaerobic landfills and consequent annual changes in landfill carbon stocks (Table 1).

Accounting for annual landfill fluxes of different waste streams, their dry-matter percentages, carbon contents, and

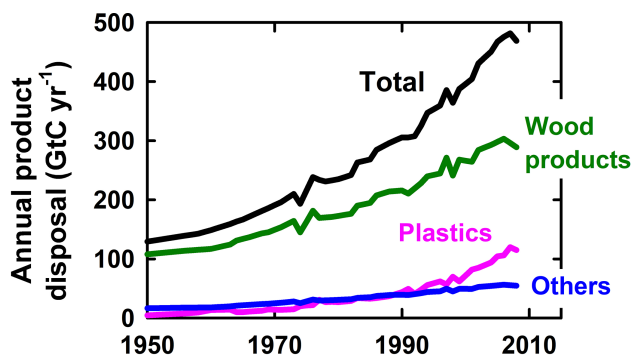

Figure 4. Annual rates of disposal of harvested-wood products, plastics and other carbon containing compounds. Based on data given in Lauk et al. (2012).

relative permanence under anaerobic conditions, we estimated changes in long-term carbon pools in landfills for different product categories. The temporal pattern of breakdown in landfills is not clear. One normally describes the breakdown of products as an exponential decay process which can be described with simple decay constants or their inverse, the residence times. However, under anaerobic conditions, breakdown effectively ceases completely, and a permanence factor essentially separates products into a fraction that breaks down over a relatively short time frame and a second fraction that does not break down at all within a time frame relevant for carbon management. The sizes of these fractions are determined by their associated degradability, such as cellulose to lignin ratios, and the biophysical conditions within landfill sites (e.g. Barlaz, 2006).

Paper and paperboard constituted the largest disposal category, but because of its relatively fast rate of degradation (Wang et al., 2011, 2015; Ximenes et al., 2015, 2018), its contribution to increasing carbon stocks is only minor. Although less wood and engineered-wood products (e.g. plywood, particle board) are disposed of in landfills than of paper and paperboard, it leads to a higher estimated storage flux because wood is highly resistant to degradation under anaerobic conditions (Ximenes et al., 2019). Plastics have the highest estimated storage flux ( $42 \mathrm{MtC} \mathrm{yr}^{-1}$ ) because of their high disposal rate, high carbon content, and very high persistence.

Using the detailed data and assumptions in Table 1, we calculated a net change in landfill storage of $88 \mathrm{MtC} \mathrm{yr}^{-1}$.

\section{River transport}

A large amount of carbon is transported from the terrestrial biosphere to the oceans through river flow. Carbon can be transported as dissolved inorganic (DIC), dissolved organic (DOC), or particulate organic (POC) carbon (Ward et al., 2017). These fluxes are difficult to quantify because of the enormous diversity of river systems (Regnier et al., 2013; Mendonca et al., 2017), and the large episodic contribution to some fluxes, especially of POC, by infrequent flood events. 
Table 1. Waste generation and estimated disposal in anaerobic landfills.

\begin{tabular}{|c|c|c|c|c|c|}
\hline Product & $\begin{array}{r}\text { Estimated total amount of material } \\
\text { disposed of in anaerobic } \\
\text { landfills }\left(\mathrm{Mt} \mathrm{yr}^{-1}\right)\end{array}$ & $\begin{array}{r}\text { Dry } \\
\text { matter } \\
(\%)\end{array}$ & $\begin{array}{l}\text { Carbon } \\
\text { fraction } \\
\qquad \%)\end{array}$ & $\begin{array}{r}\text { Carbon in long- } \\
\text { term storage } \\
(\%)\end{array}$ & 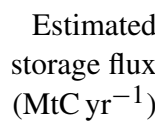 \\
\hline Wood and engineered-wood products & 67 & 89 & 48 & 98 & 28 \\
\hline Paper and paperboard & 80 & 94 & 39 & 44 & 13 \\
\hline Plastic & 57 & 100 & 75 & 95 & 41 \\
\hline Textile and rubber & 32 & 82 & 55 & 40 & 6 \\
\hline Total & 236 & & & & 88 \\
\hline
\end{tabular}

"Carbon in long-term storage" refers to the estimated proportion of waste stored permanently in anaerobic landfill sites. Total disposal estimates were derived from various sources including countries' greenhouse gas inventories for the Waste Sector, population statistics, IPCC documents (IPCC 2006, 2014), the European Atlas of Raw Materials (Prognos, 2008) and the World Bank Waste Reports (e.g. Hoornweg and Bhada-Tata, 2012). Moisture contents were obtained from Wang et al. (2015) and Ximenes et al. (2018). Carbon fractions were taken from the IPCC Good Practice Guidance (2014), and carbon-storage factors from Wang et al. (2011, 2015) and Ximenes et al. (2018). The dry matter and carbon fractions of the wood, engineered-wood products, and paper or paperboard were expressed as averages weighted by global market share of the various product categories (FAO, 2016). The estimates provided here are based on the most recent available information but were themselves based on older information largely covering the period since 2000. The numbers in bold in the bottom row have been used as our estimate of the contribution to global carbon fluxes.

Net fluxes into and out of inland water systems also consist of multiple entry points and large outgassing as some organic materials are broken down and respired as $\mathrm{CO}_{2}$ before they can be deposited in lake sediments or the oceans, while simultaneously, some new carbon is fixed through aquatic photosynthesis.

Mendonca et al. (2017) documented the largest reported emission rates per unit area for small reservoirs, with variability that extended over 3 orders of magnitude, yet global estimates had to be based on a mere 59 available point estimates. The combined surface area of these smaller reservoirs is fortunately much smaller than that of large lakes which reduce the importance of that uncertainty. Larger lakes had similar relative variabilities in observed rates but smaller averages. However, the small number of available observations clearly prevents the size of this globally important flux to be estimated with high confidence (e.g. Regnier et al., 2013).

Despite these difficulties, various authors have attempted to provide global estimates of the key fluxes (Table 2; Fig. 5). Most authors have estimated total influx to inland waterways of between 2700 and $2900 \mathrm{MtC} \mathrm{yr}^{-1}$, while the recent work by Drake et al. (2018) gave a much larger estimate of $5100 \mathrm{MtC} \mathrm{yr}^{-1}$ (Table 2). Of that amount of carbon entering inland waterways, different authors have estimated outgassing losses between 750 and $2120 \mathrm{MtC} \mathrm{yr}^{-1}$, with the estimate of Drake et al. (2018) again being much larger at $3900 \mathrm{MtC} \mathrm{yr}^{-1}$. If one uses these estimates, together with some extra inputs from mineral weathering, this leaves about $1500 \mathrm{MtC} \mathrm{yr}^{-1}$ to be either deposited in inland water bodies or transported to the oceans (Table 2). Apart from the older work of Cole et al. (2007), most other authors estimated total inland deposition as $600 \mathrm{MtC} \mathrm{yr}^{-1}$ and total flux to the ocean as $900 \mathrm{MtC} \mathrm{yr}^{-1}$, broken down into a DIC flux of $450 \mathrm{MtC} \mathrm{yr}^{-1}$, POC flux of about $250 \mathrm{MtC} \mathrm{yr}^{-1}$, and DOC flux of $200 \mathrm{MtC} \mathrm{yr}^{-1}$. Romankevich et al. (2009) estimated an additional contribution of $47 \mathrm{MtC} \mathrm{yr}^{-1}$ from coastal erosion, ground-water influx, and glacial run-off.

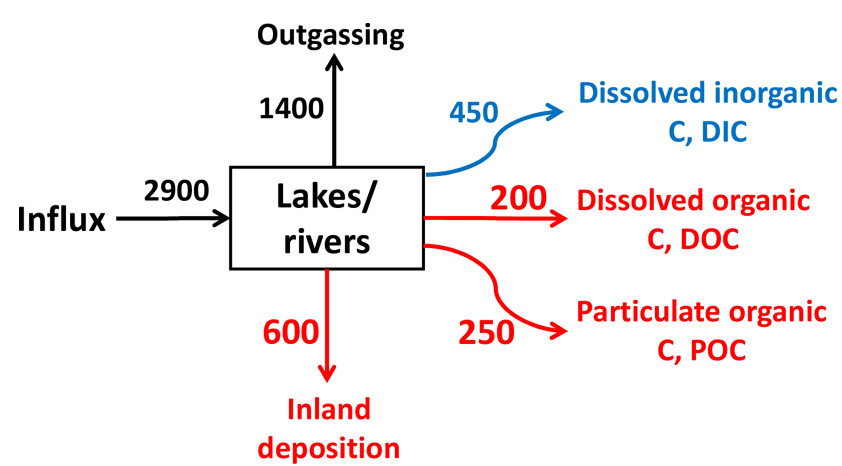

Figure 5. The main carbon fluxes in $\mathrm{MtC} \mathrm{yr}^{-1}$ involving inland waterways. The number shown in blue is already included in the global carbon budget, whereas the numbers in red should be added to the revised global carbon budget. The numbers in black do not need to be included explicitly.

Considering the evidence used by the various authors, we consider total carbon flux to inland waterways to most likely be about $2900 \mathrm{MtC} \mathrm{yr}^{-1}$ (Fig. 5; Table 2). About half of that $\left(1400 \mathrm{MtC} \mathrm{yr}^{-1}\right)$ is lost from waterways by outgassing, although neither of those estimates are needed for explicit inclusion in the global budget. The important flux is the transport to the oceans, consisting of $450 \mathrm{MtC} \mathrm{yr}^{-1}$ DIC, $200 \mathrm{MtC} \mathrm{yr}^{-1}$ DOC, and $250 \mathrm{MtC} \mathrm{yr}^{-1}$ POC (Table 2). The DIC flux is already included in the estimate of total inorganic ocean uptake, but the DOC and POC fluxes have not been included in the global summary numbers of Le Quéré et al. (2018). In addition, between 60 and $250 \mathrm{MtC} \mathrm{yr}^{-1}$ are deposited in lakes and water reservoirs (Mendonca et al., 2017). Other studies have also included deposition in wetlands, floodplains and sediments for a total deposition estimate of about $600 \mathrm{MtC} \mathrm{yr}^{-1}$ in all inland water bodies (Tranvik et al., 2009; Aufdenkampe et al., 2011). This flux has also not yet been included in the global flux quantification of Le Quéré et al. (2018). 
Table 2. Summary of prior estimates of the main components of carbon fluxes through inland waterways.

\begin{tabular}{|c|c|c|c|c|c|c|c|c|}
\hline & Influx & Efflux (evasion) & DOC & POC & Total organic & DIC & Total river & C depos. \\
\hline Stallard (1998) & & & 230 & 300 & & 290 & & \\
\hline Schlünz and Schneider (2000) & & & & & 434 & 450 & & \\
\hline Richey (2004) & & & & & & & 800 & \\
\hline Seitzinger et al. (2005) & & & 170 & 197 & & & & \\
\hline Cole (2007) & 1900 & 750 & & & & 450 & & 230 \\
\hline Tranvik et al. (2009) & 2900 & 1400 & & & & & & 600 \\
\hline Romankevich et al. (2009) & & & 210 & 370 & $627^{*}$ & & & \\
\hline Aufdenkampe et al. (2011) & 2700 & 1200 & & & & & 900 & 600 \\
\hline Raymond et al. (2013) & & 2120 & & & & & & \\
\hline Regnier et al. (2013) & & 1100 & 200 & 200 & & 400 & & 600 \\
\hline Drake et al. (2018) & 5100 & 3900 & & & & & & \\
\hline Our estimate & 2900 & 1400 & 200 & 250 & 450 & 450 & 900 & 600 \\
\hline
\end{tabular}

\section{Aeolian fluxes}

Carbon can also be transported from the land to the oceans by aeolian transport through wind erosion of dust particles (Zender et al., 2003; Webb et al., 2012). These carbon fluxes to the ocean are not captured in air-sea $\mathrm{CO}_{2}$ exchange but add to the total flux of carbon from the land to the ocean (see Fig. 2).

Romankevich (1984) estimated aeolian carbon flux as $320 \mathrm{MtC} \mathrm{yr}^{-1}$, while Romankevich et al. (2009) estimated it as $96 \mathrm{MtC} \mathrm{yr}^{-1}$. Estimates can also be based on independently estimating the annual flux of aeolian dust and its carbon concentrations. Mahowald et al. (2005) summarised the different available estimates of the total aeolian dust flux as $1500-2000 \mathrm{Mt}$ (dust) $\mathrm{yr}^{-1}$. Assuming source carbon concentrations between $1 \%$ and $2 \%$ (Webb et al., 2012; Chappell et al., 2013) and a 2.5-fold enrichment of carbon concentrations in dust relative to source concentrations (Webb et al., 2005), it leads to a global flux estimate of $50-100 \mathrm{MtC} \mathrm{yr}^{-1}$.

\section{Charcoal}

A sizable fraction of annually produced biomass is burnt each year (Kuhlbusch and Crutzen, 1995). Savannah vegetation is particularly prone to annual burning, and a fraction of burnt material is not combusted completely but remains as charcoal, estimated as 50-270 $\mathrm{MtC} \mathrm{yr}^{-1}$ (Forbes et al., 2006). A small fraction of that will become airborne, either during fires themselves or in subsequent wind storms, and a small proportion of that airborne fraction will be transported to the oceans. Forbes et al. (2006) estimated this flux to be less than $10 \mathrm{MtC} \mathrm{yr}^{-1}$.

\section{Methane and NMVOCs}

The principal gas transfer of carbon to the oceans is via $\mathrm{CO}_{2}$, but carbon can also reach the ocean in organic gaseous form (Fowler et al., 2009). The annual combined flux of methane and NMVOCs is estimated to be about $1.3 \mathrm{GtC} \mathrm{yr}^{-1}$, with methane fluxes contributing about $500 \mathrm{MtC} \mathrm{yr}^{-1}$ (Ciais et al., 2013; Kirschke et al., 2013) and NMVOCs about $800 \mathrm{MtC} \mathrm{yr}^{-1}$ (Fowler et al., 2009), more than half of which is isoprene. Most of these compounds are oxidised in the troposphere, with methanol, methyl hydroperoxide, and formaldehyde as key intermediate oxidation products (Fig. 6). If these compounds were fully oxidised to $\mathrm{CO}_{2}$ in the atmosphere, there would be a simple closed loop between production by the terrestrial biosphere and atmospheric oxidation, but any transfer to the ocean by compounds other than $\mathrm{CO}_{2}$ constitutes an additional carbon transfer from land to the ocean (see Fig. 2) that is not otherwise captured in the budget.

This transfer can be by direct transfer to the surface ocean or after prior solution in raindrops. This direct flux of methane and isoprene is probably small due to their low water solubility. However, under partial oxidation in the atmosphere, major intermediate products are methanol, organic acids, and formaldehyde, which are all highly soluble in water and can be deposited in the oceans as wet (after dissolution in rain or fog) or "dry" deposition when gases dissolve directly in ocean water. As we are not aware of prior estimates of this flux, we have estimated wet and dry deposition of the relevant compounds here, including a separation between land and ocean deposition (Table 3). Details of the calculation methods are given in the Supplement.

The compounds in Table 3 show the quantitatively important intermediate oxidation products of methane, isoprene, and other NMVOCs. We calculated a total ocean dry deposi- 
Table 3. Estimated annual carbon fluxes to the world's oceans and globally (values in brackets) from dry and wet deposition of VOCs and

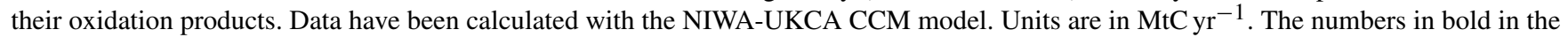
bottom rows have been used as our estimate of the contribution to global carbon fluxes.

\begin{tabular}{|c|c|c|}
\hline & $\begin{array}{r}\text { Global dry } \\
\text { ocean deposition }\end{array}$ & $\begin{array}{l}\text { Global wet } \\
\text { ocean deposition }\end{array}$ \\
\hline Formaldehyde (HCHO) & $3.4(9.5)$ & $11.1(23.1)$ \\
\hline Methyl hydroperoxide $\left(\mathrm{CH}_{3} \mathrm{OOH}\right)$ & $3.6(5.1)$ & $5.2(7.3)$ \\
\hline Methanol $\left(\mathrm{CH}_{3} \mathrm{OH}\right)$ & $2.4(11.8)$ & $2.7(6.7)$ \\
\hline Formic acid $(\mathrm{HCOOH})$ & $0.1(1.2)$ & $2.3(9.7)$ \\
\hline Peracetic acid $\left(\mathrm{CH}_{3} \mathrm{COOOH}\right)$ & $0.1(0.8)$ & $1.1(2.7)$ \\
\hline Acetic acid $\left(\mathrm{CH}_{3} \mathrm{COOH}\right)$ & $0.5(1.5)$ & $8.6(16.3)$ \\
\hline Other $\mathrm{C}_{3}-\mathrm{C}_{5}$ isoprene and monoterpene oxidation products & $0.7(8.3)$ & $8.1(80.4)$ \\
\hline 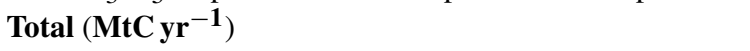 & $10.8(38.2)$ & $39.1(146.2)$ \\
\hline 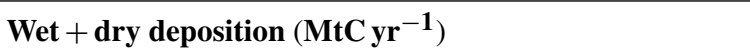 & \multicolumn{2}{|c|}{$49.9(184.4)$} \\
\hline
\end{tabular}

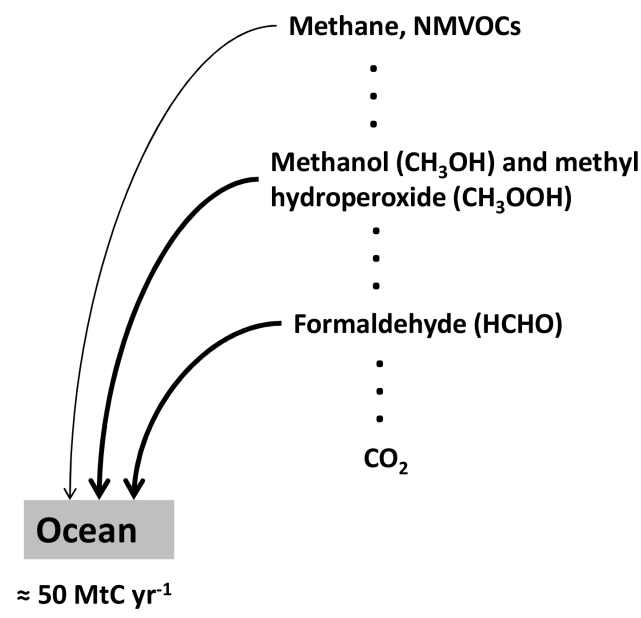

Figure 6. The main fluxes involved in the transfers of methane and NMVOCs to the oceans. Details of the estimated fluxes are given in Table 3.

tion of 10.8 $\mathrm{MtC} \mathrm{yr}^{-1}$ and wet deposition of $39.1 \mathrm{MtC} \mathrm{yr}^{-1}$, which together account for around $27 \%$ of total surface deposition (with $73 \%$ assumed to occur over land). Some of these intermediate products have short lifetimes and are, therefore, mainly deposited close to their points of production, which are mostly over land areas.

Summing these various fluxes provides an additional $\sim 50 \mathrm{MtC} \mathrm{yr}^{-1}$ of non- $\mathrm{CO}_{2}$ flux from the atmosphere to the oceans. Any estimate of global fluxes depends strongly on deposition schemes, chemical mechanisms, and terrestrial NMVOC emissions, which vary among global models and are poorly constrained by observations. Hence, there are considerable uncertainties in these estimated fluxes, as demonstrated by Jacob et al. (2005), for example, in the case of the global methanol budget. They summarised the results of various previous studies and reported global dry deposition on the oceans estimated by different models of $0.3-$
$50 \mathrm{Mt}\left(\mathrm{CH}_{3} \mathrm{OH}\right) \mathrm{yr}^{-1}$ plus total global wet deposition of 9$50 \mathrm{Mt}\left(\mathrm{CH}_{3} \mathrm{OH}\right) \mathrm{yr}^{-1}$ which was not separated between land and ocean deposition.

This illustrates the remaining levels of uncertainties in these global estimates. There are also considerable differences in isoprene and monoterpene oxidation mechanisms among the models, in particular the formation of intermediate products from isoprene oxidation (e.g. Paulot et al., 2009). Some further information on these uncertainties is given in the Supplement.

\section{Summary of the main fluxes in the global carbon cycle}

Consideration of these additional pools and fluxes reduces the estimated additional carbon stored in the terrestrial biosphere, $\Delta B_{\text {phys }}$, from 3.6 to $2.1 \mathrm{GtC} \mathrm{yr}^{-1}$ (Fig. 7, Table 4). While none of the various extra fluxes are particularly large or important on their own, added together they reduce the size of the inferred terrestrial biosphere sink by about $1.5 \mathrm{GtC} \mathrm{yr}^{-1}$.

For greater transparency, it would also be desirable to explicitly include harvested-wood products and landfill pools. The associated carbon flux is already included under the netland-use calculations (Le Quéré et al., 2018). Inclusion of a harvested-wood-products pool, therefore, would not affect the size of the residual sink, but it would require a corresponding adjustment of the net land-use-change flux.

The fluxes into increasing pools of plastics, bitumen, and waste storage in landfills are clear and obvious fluxes that are quantitatively important and additional to fluxes currently considered by Le Quéré et al. (2018). Their effect on the overall budget had, however, already been included indirectly in the fossil-fuel fluxes through a term that accounts for incomplete oxidation of fossil-fuel use (Marland and Rotty, 1984). The fluxes into the increasing pools of plastic and bitumen are reasonably well constrained. The flux into in- 


\section{7-2016}

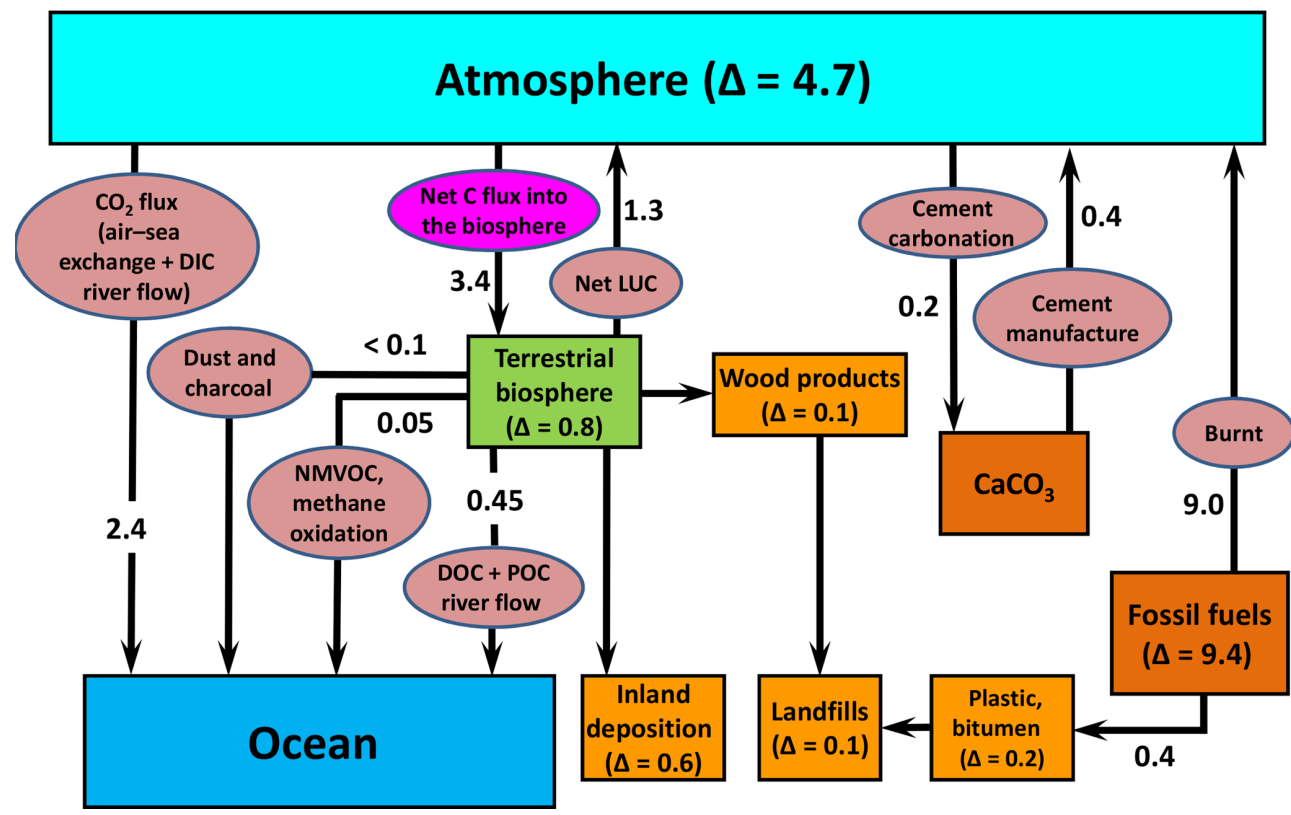

Figure 7. Expanded summary of the main components of the global carbon cycle for the 2007-2016 period. The fluxes are those given by Le Quéré et al. (2018) as shown in Fig. 1 above. These broad fluxes have then been modified based on Table 4 and the details provided in specific sections above. Rectangular boxes refer to identified important carbon storage pools in the global carbon budget. Fluxes described in ovals refer to key fluxes between these storage pools.

Table 4. Adjustments to the estimated change in the terrestrial biosphere $\left(\mathrm{GtC} \mathrm{yr}^{-1}\right)$. The term $\Delta B_{\text {act }}$ refers to all actual biospheric carbon-stock changes, including those due to LUC whereas $\Delta B_{\text {phys }}$ excludes LUC effects and includes only physiological and age-class effects. The "inferred flux into the biosphere" is calculated as the residual sink minus cement carbonation.

\begin{tabular}{lr}
\hline Original residual uptake & 3.6 \\
Cement carbonation & -0.2 \\
Revised inferred flux into the biosphere & 3.4 \\
inland deposition & -0.6 \\
river transport (DOC, POC) & -0.45 \\
Flux of methane, NMVOC + intermediates & -0.05 \\
Aeolian dust transport & -0.05 \\
Harvested-wood-products pool & -0.1 \\
\hline Change in landfill pool originating & -0.05 \\
from harvested-wood products & \\
\hline LUC & -1.3 \\
$\Delta B_{\text {act }}$ & 0.8 \\
$\Delta B_{\text {phys }}$ & 2.1 \\
\hline
\end{tabular}

creasing landfill carbon storage is less well constrained, as we could find no prior global assessment of this flux. We have provided the first such global estimate in the present work, but significant uncertainty remains due to incomplete knowledge of regional details of the key properties of differ- ent waste streams. In any case, explicit inclusion of fluxes into these storage pools would be desirable to increase transparency of the overall global carbon budget.

These incomplete oxidation terms for fossil-fuel use (Marland and Rotty, 1984) account for incomplete combustion during energy generation and for non-fuel uses. That has been represented explicitly in Fig. 7. For internal consistency, the fossil-fuel consumption rates have therefore been

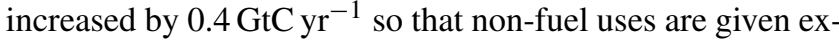
plicitly in Fig. 7. While, for transparency, it would be desirable to make these fluxes explicit, it would not affect the estimated size of the residual sink.

Cement carbonation is an additional sink that is likely to increase in proportion to the cumulative total amount of manufactured cement and is, therefore, likely to increase further into the future. Its magnitude is also reasonably well constrained and is clearly bounded by the total historical cement production. This flux has so far been omitted from the global carbon budget, and its inclusion reduces the size of the residual sink.

River transport as DOC and POC is also reasonably well constrained even though the enormous heterogeneity of river types makes confident assessment difficult. This is further compounded by the disproportionate importance of rare flooding events that can episodically transport large quantities of particulate organic matter. Nonetheless, the vari- 
ous global estimates are converging on similar flux estimates (e.g. Regnier et al., 2013; Drake et al., 2018).

A fraction of this organic carbon flux is oxidised in the shallow ocean, leading to outgassing in some regions (e.g. Borges et al., 2005; Jacobson et al., 2007). Another fraction is transferred to the ocean floor or the deep ocean in organic form. POC associated with soil minerals is particularly prone to direct sinking to the ocean floor. That mineral-associated fraction should obviously be included. The fraction that is oxidised in the shallow ocean and converted to inorganic carbon will increase the surface $p \mathrm{CO}_{2}$ (partial pressure of $\mathrm{CO}_{2}$ ). This lowers the atmosphere-to-ocean $\mathrm{CO}_{2}$ gradient and reduces ocean $\mathrm{CO}_{2}$ uptake, or can even lead to outgassing. Calculations of ocean $\mathrm{CO}_{2}$ uptake by gaseous exchange could be correctly estimated without bias, but total transfer of $\mathrm{CO}_{2}$ to the surface ocean will be the combined flux of air-sea exchange plus the additional contribution of organic carbon that found its way to the ocean by aeolian or river transfer, or by gas transfer of non- $\mathrm{CO}_{2}$ carbon compounds. Regardless of those further transformations, Fig. 2 showed that it would be appropriate to include this flux of organic carbon as an important addition to the overall budget.

Deposition of carbon in inland waterways is another quantitatively important flux into an additional carbon storage pool that should be included in the overall budget. With the increasing regulation of waterways and the construction of more dams on the world's rivers (e.g. Regnier et al., 2013), and possible increases in erosion fluxes (e.g. Yang et al., 2003), this flux is also likely to continue to increase into the future.

Some of the erosion-related components of this flux constitute a simple lateral carbon transfer from erosion sites to some downstream waterways with no net effect on the atmosphere. However, most denuded erosion sites can eventually regain their lost soil organic carbon. While that process is slow and may remain incomplete, the resultant potential carbon gain needs to also be factored in (van Oost et al., 2007). It would, therefore, be too simplistic to ignore inland deposition as just a lateral transfer. In its totality, erosion may act as a net sink or source of carbon to the atmosphere. For global carbon accounting purposes, it means that inland deposition should be included, but any changes in soil carbon stocks also need to be quantified to complete the overall balance.

The next relevant flux is the transport of carbon attached to aeolian dust or charcoal. Again, this flux transfers carbon from the land surface to the oceans through means that are not quantified through $\mathrm{CO}_{2}$ exchange at the airsurface interchange. This flux may contribute an additional $50-100 \mathrm{MtC} \mathrm{yr}^{-1}$. Finally, methane, NMVOCs, and their intermediate oxidation products can be transferred directly to the oceans. As with river and aeolian transport, the subsequent fate of these products after they reach the oceans does not change their important role as a carbon-transfer mechanism, and therefore these fluxes should be included. Here,

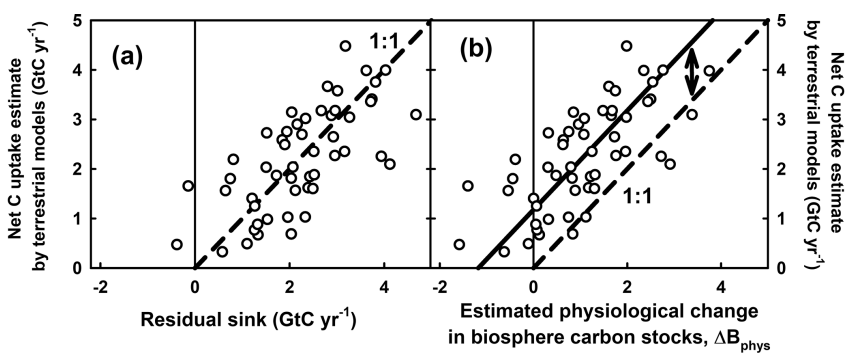

Figure 8. Mean estimates of net carbon uptake by the biosphere plotted against the residual sink (a), or as a function of the revised $\Delta B_{\text {phys }}$ calculated here (b). Data have been taken from Le Quéré et al. (2018), with each point corresponding to an annual flux estimate since 1959. Data were calculated as given in Eq. (1). The dashed lines are 1:1 lines, and the solid line in (b) is off-set by $1.2 \mathrm{GtC} \mathrm{yr}^{-1}$ but retains a slope of 1 .

we have provided a first global estimate of the size of these combined fluxes of about $50 \mathrm{MtC} \mathrm{yr}^{-1}$.

The sizes of these various fluxes have been estimated in previous publications that have focused on one process or another, or they have been calculated based on existing underlying information where no prior global estimates could be found. The novel contribution of the present analysis is bringing these fluxes together in a combined assessment (Fig. 7), which has not previously been done. While the exact magnitude of some of these fluxes remains uncertain, it is clear that they are not zero. Their exclusion from past global carbon budgets has, therefore, systematically inflated the size of the estimated $\Delta B_{\text {phys. }}$ It is, therefore, warranted to include them in future budgets and move towards a better, and less biased, estimate of $\Delta B_{\text {phys }}$ and the residual sink strength of the terrestrial biosphere.

\section{Implications for biosphere models}

The residual sink is often implicitly or explicitly equated with net exchange by the biosphere, with the two flux estimates even presented on the same graph by Ciais et al. (2013), and Le Quéré et al. (2018) referred to the residual sink as the "land sink". The size of the residual sink has thus been used as an important reality check of the structure and parameterisation of existing biosphere models.

However, equating the residual sink to $\Delta B_{\text {phys }}$ without accounting for these additional fluxes has led to an overestimation of $\Delta B_{\text {phys }}$ with important implications for our assessment of the veracity of existing biosphere models (Fig. 8). Taking the annual flux estimates generated by the average of accepted biosphere models and the size of the originally calculated residual sink, one obtains a fairly good relationship, with estimates largely conforming to a $1: 1$ relationship (Fig. 8a).

If one expresses the flux estimates of the biosphere models against the revised estimates of $\Delta B_{\text {phys }}$, however, the match 
against the $1: 1$ line is poor. There is a large discrepancy with the biosphere models estimating sink activity that is about $1.0-1.5 \mathrm{GtC} \mathrm{yr}^{-1}$ higher than the corresponding estimates of the revised residual sink activity (Fig. 8b). This suggests that current biosphere models systematically overestimate biospheric carbon uptake, which has important implications for present-day overall global carbon fluxes. It suggests that biosphere models may similarly overpredict future carbon uptake rates. If enhanced carbon uptake by the terrestrial biosphere in response to climate change, including increasing atmospheric $\mathrm{CO}_{2}$, is overestimated, it will similarly overestimate the extent by which biospheric feedbacks could negate future anthropogenic greenhouse gas emissions.

\section{General discussion}

An understanding of the global carbon cycle is important for a full appreciation of the anthropogenic disturbance of the cycle, and to what extent that disturbance is negated, or amplified, through natural feedback processes. It is even more important as a guide to the magnitude of future feedback processes (e.g. Cramer et al., 2001; Friedlingstein et al., 2006; Jones et al., 2013; Huntzinger et al., 2017). It is important to anticipate whether any current carbon uptake by the biosphere may be reversed under future climatic conditions, especially under ongoing and intensifying warming (e.g. Kirschbaum, 2000), while plants may become less responsive to $\mathrm{CO}_{2}$ as atmospheric concentrations trend towards $\mathrm{CO}_{2}$ saturation (e.g. Friedlingstein et al., 2006).

The comparisons between the residual sink and biospheric net $\mathrm{CO}_{2}$ uptake have been given explicitly by the IPCC (Ciais et al., 2013), and they play an important role as a reality check of global biosphere models (e.g. Arneth et al., 2017; Huntzinger et al., 2017). However, to fulfil that role, it is essential that the comparisons use comparable data. It is therefore important to calculate $\Delta B_{\text {phys }}$ after the various known terms listed above have been explicitly quantified and subtracted from the "residual sink".

To correctly anticipate whether future natural biospheric carbon exchange will add to or subtract from anthropogenic emissions, it is essential to assign sink activity to the appropriate processes. If sink activity is assumed to relate to net uptake by the biosphere, one might expect it to respond to factors such as the age class distribution of forests, or temperature, precipitation, $\mathrm{CO}_{2}$ concentration, or land management. If one incorrectly infers the sensitivity of the system to these external factors, it would be impossible to predict future biospheric responses.

The various factors identified above respond to different drivers. Aeolian fluxes, for example, might respond to climate variability like the ENSO cycle and longer-term landuse and management choices, and fluxes related to the oxidation of methane and NMVOCs would be proportional to the underlying fluxes of methane and NMVOCs. Storage in increasing pools of plastic, bitumen, and landfills, as well as cement carbonation, are clearly determined by anthropogenic factors, such as economic and technological development. Future fluxes, therefore, will not respond to future temperature or $\mathrm{CO}_{2}$ concentration, but need to be assessed through assessment of socio-economic developments.

Terrestrial net carbon exchange can be further subdivided into at least four distinct processes,

\subsection{Growth rate changes related to forest age}

Forest growth tends to be highest in young stands and decreases as stands age (Ryan et al., 1997; Kurz and Apps, 1999). Any net forest growth can therefore be due to the rebound of forest biomass after prior disturbance through anthropogenic or natural processes. Disturbance may be through the harvesting of established forests or the planting of new ones, or due to natural factors, such as wildfire or insect-pest outbreaks (e.g. Stinson et al., 2011). The presence of a global net forest sink implies that new growth exceeds losses through wood extraction and other disturbance factors. A forest sink can be caused by disturbance-related carbon losses in preceding years. Understanding forest growth under current and future conditions therefore requires disturbance effects and age-class distributions to be combined with an assessment of biophysical growth factors (e.g. Chen et al., 2000). Many of the world's forests are now being inventoried at regular intervals (Pan et al., 2011), which can be supplemented with remotely sensed information (Dong et al., 2003). Growth responses can be inferred from these changes in age-class distribution (Stinson et al., 2011), although subtler disturbance-related effects on woody biomass are difficult to fully capture at the global scale and may have led to past underestimation of carbon emissions related to landuse change (Arneth et al., 2017), with a consequent larger rebound potential as well.

\subsection{Growth rate changes related to biophysical drivers}

In principle, growth can be enhanced by increasing $\mathrm{CO}_{2}$ concentrations (Pugh et al., 2016; Hickler et al., 2015), nitrogen deposition from industrial pollution (LeBauer and Treseder, 2008), or climatic changes apart from increasing $\mathrm{CO}_{2}$ concentrations, such as by increasing temperatures (Reyer, 2015; Sitch et al., 2015). Most modelling work has focused on these drivers as they can most easily be generalised and predicted into the future, but their actual importance remains uncertain (Arneth et al., 2017; Huntzinger et al., 2017), especially in relation to age-class effects of forests that might be the principal driver of any change in the sink-source balance of forests as discussed under the previous point. It is also likely that forests subject to nutrient limitations are less responsive to changes in other biophysical drivers (e.g. Kirschbaum et al., 1998; Norby et al., 2010; Huntzinger et al., 2017) as nutri- 
ent availability can retain an over-riding importance for stand productivity.

\subsection{Blue carbon}

It has been recognised that mangrove forests, seagrass beds, and salt marshes can sequester large amounts of carbon, recently termed "blue carbon" (McLeod et al., 2011; Huxham et al., 2018). It has been estimated to constitute a global carbon sink of at least $200 \mathrm{MtC} \mathrm{yr}^{-1}$ (McLeod et al., 2011) or even more (Breithaupt et al., 2012). However, infrastructure development of coastal habitats not only prevents ongoing carbon sequestration by these ecosystems but can also lead to the release of the large carbon stocks of these systems. Overall, such development may result in comparable annual carbon losses as the ongoing sequestration by intact systems (e.g. Pendleton et al., 2012; Regnier et al., 2013; Atwood et al., 2017).

\subsection{Soil organic carbon}

There may also be changes in soil carbon that can be very difficult to detect. Globally, there are about $2500 \mathrm{GtC}$ in soil organic matter to a depth of $2 \mathrm{~m}$ (Batjes, 2004) so that a change by just $0.4 \% \mathrm{yr}^{-1}$ would equate to a flux of $10 \mathrm{GtC} \mathrm{yr}^{-1}$ to or from the atmosphere (Minasny et al., 2017). Such a change could be readily associated with land-use changes (e.g. Guo and Gifford, 2002; Kim and Kirschbaum, 2015). They may also correspond to episodic changes within given land uses, especially changes related to accelerated erosion under agricultural land use (e.g. van Oost et al., 2007; Quinton et al., 2010; de Rose, 2013).

Observational verification of annual changes of the order of $0.4 \% \mathrm{yr}^{-1}$ is extremely difficult owing to the many important factors that may positively or negatively affect soil carbon levels under different circumstances and over different timescales (e.g. Schipper et al., 2017). However, even such proportionately small changes could be very important in the global budget and have become the basis of the recent 4 per mille initiative (e.g. Minasny et al., 2017) which aims to promote land-use practices to increase soil carbon by that amount.

\section{Conclusions}

It is important to ensure that anthropogenic $\mathrm{CO}_{2}$ emissions do not lead to changes in atmospheric $\mathrm{CO}_{2}$ concentrations with dangerous consequences for nature and society. A good understanding of the global carbon budget is essential for a good assessment of current and likely future trends in carbon stocks and fluxes. However, the global carbon budget in its currently used form is overly simplified and, therefore, does not provide appropriate guidance on the way anthropogenic and natural processes interact to lead to the observed increases in atmospheric concentrations. It also does not provide sufficient detail on some important component fluxes, which hinders a full appreciation of their role in the global budget. These simplifications warrant modifications to the budget to explicitly and comprehensively include other known carbon fluxes between major carbon pools. While the magnitude of these various fluxes remains uncertain, understanding of the key processes has grown over the years so that it has become appropriate for these additional fluxes to be explicitly included in future global budgets.

The greatest practical importance of that inclusion lies in the role of the global budget as a reality check for the development and parameterisation of global biosphere models. Past omission of the various known but omitted carbon fluxes discussed here is likely to have inflated the estimated sizes of natural sink activity. To provide a truer guide for the role and magnitude of these natural fluxes, it is warranted to provide a revised and more detailed assessment of the most likely changes in biospheric carbon stocks. The global carbon budget is a key analysis tool for understanding the anthropogenic effect on disturbing that budget. As such, it plays a key role in informing the global research and policy-making community on trends in carbon dynamics, and ongoing refinement is warranted and necessary to fully fulfil that important role.

Data availability. The data used for Figs. 3, 4, and 8 are given in the Supplement. Detailed data, from which the numbers in Table 3 have been calculated, are available at https://doi.org/10.5281/zenodo.2556996 (Kirschbaum et al., 2019).

Supplement. The supplement related to this article is available online at: https://doi.org/10.5194/bg-16-831-2019-supplement.

Author contributions. MUFK designed the work and conducted the main analyses; FX conducted the detailed analysis of landfill carbon-storage fluxes; GZ conducted the detailed analysis of VOC fluxes to the oceans; JRZ analysed the carbon fluxes related to river transport. MUFK primarily wrote the manuscript with input from all co-authors, especially DLG.

Competing interests. The authors declare that they have no conflict of interest.

Special issue statement. This article is part of the special issue "The 10th International Carbon Dioxide Conference (ICDC10) and the 19th WMO/IAEA Meeting on Carbon Dioxide, other Greenhouse Gases and Related Measurement Techniques (GGMT-2017) (AMT/ACP/BG/CP/ESD inter-journal SI)". It is a result of the 10th International Carbon Dioxide Conference, Interlaken, Switzerland, 21-25 August 2017. 
Acknowledgements. We would like to thank Robbie Andrew, Pep Canadell, Andrew McMillan, Sara Mikaloff-Fletcher, and both anonymous reviewers for useful contributions to the underlying concepts discussed here, particularly on the details of some of the calculations embedded in the annual carbon budget published by the Global Carbon Project, and for providing specific comments on the manuscript. We would also like to thank Anne Austin for scientific editing.

We acknowledge funding by the New Zealand Government's Strategic Science Investment Fund (SSIF), the UK Met Office for use of the MetUM, and the contribution of NeSI high-performance computing facilities funded jointly by NeSI's collaborator institutions and New Zealand's MBIE's Research Infrastructure programme (https://www.nesi.org.nz, last access: 28 January 2019).

Edited by: Paul Stoy

Reviewed by: two anonymous referees

\section{References}

Andres, R. J., Boden, T. A., Bréon, F.-M., Ciais, P., Davis, S., Erickson, D., Gregg, J. S., Jacobson, A., Marland, G., Miller, J., Oda, T., Olivier, J. G. J., Raupach, M. R., Rayner, P., and Treanton, K.: A synthesis of carbon dioxide emissions from fossil-fuel combustion, Biogeosciences, 9, 1845-1871, https://doi.org/10.5194/bg-9-1845-2012, 2012.

Andrew, R. M.: Global $\mathrm{CO}_{2}$ emissions from cement production, Earth Syst. Sci. Data, 10, 195-217, https://doi.org/10.5194/essd10-195-2018, 2018.

Arneth, A., Sitch, S., Pongratz, J., Stocker, B. D., Ciais, P., Poulter, B., Bayer, A. D., Bondeau, A., Calle, L., Chini, L. P., Gasser, T., Fader, M., Friedlingstein, P., Kato, E., Li, W., Lindeskog, M., Nabel, J. E. M. S., Pugh, T. A. M., Robertson, E., Viovy, N., Yue, C., and Zaehle, S.: Historical carbon dioxide emissions caused by land-use changes are possibly larger than assumed, Nat. Geosci., 10, 79-86, 2017.

Atwood, T. B., Connolly, R. M., Almahasheer, H., Carnell, P. E., Duarte, C. M., Lewis, C. J. E., Irigoien, X., Kelleway, J. J., Lavery, P. S., Macreadie, P. I., Serrano, O., Sanders, C. J., Santos, I., Steven, A. D. L., and Lovelock, C. E.: Global patterns in mangrove soil carbon stocks and losses, Nat. Clim. Change, 7, 523$529,2017$.

Aufdenkampe, A. K., Mayorga, E., Raymond, P. A., Melack, J. M., Doney, S. C., Alin, S. R., Aalto, R. E., and Yoo, K.: Riverine coupling of biogeochemical cycles between land, oceans, and atmosphere, Front. Ecol. Environ., 9, 53-60, 2011.

Barlaz, M. A.: Forest products decomposition in municipal solid waste landfills, Waste Manage., 26, 321-333, 2006.

Batjes, N. H.: Total carbon and nitrogen in the soils of the world, Eur. J. Soil Sci., 65, 10-21, 2004.

Borges, A.V., Delille, B., and Frankignoulle, M.: Budgeting sinks and sources of $\mathrm{CO}_{2}$ in the coastal ocean: Diversity of ecosystems counts, Geophys. Res. Lett., 32, 1-4, 2005.

Breithaupt, J. L., Smoak, J. M., Smith, T. J., Sanders, C. J., and Hoare, A.: Organic carbon burial rates in mangrove sediments: Strengthening the global budget, Global Biogeochem. Cy., 26, GB3011, https://doi.org/10.1029/2012GB004375, 2012.
Brunet-Navarro, P., Jochheim, H., and Muys, B.: Modelling carbon stocks and fluxes in the wood product sector: a comparative review, Glob. Change Biol., 22, 2555-2569, 2016.

Ciais, P., Sabine, C., Bala, G., Bopp, L., Brovkin, V., Canadell, J., Chhabra, A., DeFries, R., Galloway, J., Heimann, M., Jones, C., Le Quéré, C., Myneni, R. B., Piao, S., and Thornton, P.: Carbon and Other Biogeochemical Cycles, in: Climate Change 2013: The Physical Science Basis, Contribution of Working Group I to the Fifth Assessment Report of the Intergovernmental Panel on Climate Change, edited by: Stocker, T. F., Qin, D., Plattner, G.K., Tignor, M., Allen, S. K., Boschung, J., Nauels, A., Xia, Y., Bex V., and Midgley, P. M., Cambridge University Press, Cambridge, United Kingdom and New York, NY, USA, 465-570, 2013.

Chappell, A., Webb, N. P., Butler, H. J., Strong, C. L., McTainsh, G. H., Leys, J. F., and Rossel, R. A. V.: Soil organic carbon dust emission: an omitted global source of atmospheric $\mathrm{CO}_{2}$, Glob. Change Biol., 19, 3238-3244, 2013.

Chen, J., Chen, W. J., Liu, J., Cihlar, J., and Gray, S.: Annual carbon balance of Canada's forests during 1895-1996, Global Biogeochem. Cy., 14, 839-849, 2000.

Cole, J. J., Prairie, Y. T., Caraco, N. F., McDowell, W. H., Tranvik, L. J., Striegl, R. G., Duarte, C. M., Kortelainen, P., Downing, J. A., Middelburg, J. J., and Melack, J.: Plumbing the global carbon cycle: Integrating inland waters into the terrestrial carbon budget, Ecosystems, 10, 171-184, 2007.

Cramer, W., Bondeau, A., Woodward, F. I., Prentice, I. C., Betts, R. A., Brovkin, V., Cox, P. M., Fisher, V., Foley, J. A., Friend, A. D., Kucharik, C., Lomas, M. R., Ramankutty, N., Sitch, S., Smith, B., White, A., and Young-Molling, C.: Global response of terrestrial ecosystem structure and function to $\mathrm{CO}_{2}$ and climate change: results from six dynamic global vegetation models, Glob. Change Biol., 7, 357-373, 2001.

De Rose, R. C.: Slope control on the frequency distribution of shallow landslides and associated soil properties, North Island, New Zealand, Earth Surf. Proc. Land., 38, 356-371, 2013.

Dong, J. R., Kaufmann, R. K., Myneni, R. B., Tucker, C. J., Kauppi, P. E., Liski, J., Buermann, W., Alexeyev, V., and Hughes, M. K.: Remote sensing estimates of boreal and temperate forest woody biomass: carbon pools, sources, and sinks, Remote Sens. Environ., 84, 393-410, 2003.

Drake, T. W., Raymond, P. A., and Spencer, R. G. M.: Terrestrial carbon inputs to inland waters: A current synthesis of estimates and uncertainty, Limnol. Oceanogr. Lett., 3, 132-142, 2018.

FAO: FAOSTAT-Forestry Database, Food and Agriculture Organization (FAO) of the United Nations, available at: http://www.fao org/forestry/statistics/en/ (last access: 28 January 2019), 2016.

Forbes, M. S., Raison, R. J., and Skjemstad, J. O.: Formation, transformation and transport of black carbon (charcoal) in terrestrial and aquatic ecosystems, Sci. Total Environ., 370, 190-206, 2006.

Fowler, D., Pilegaard, K., Sutton, M. A., Ambus, P., Raivonen, M., Duyzer, J., Simpson, D., Fagerli, H., Fuzzi, S., Schjoerring, J K., Granier, C., Neftel, A., Isaksen, I. S. A., Laj, P., Maione, M., Monks, P. S., Burkhardt, J., Daemmgen, U., Neirynck, J., Personne, E., Wichink-Kruit, R., Butterbach-Bahl, K., Flechard, C., Tuovinen, J. P., Coyle, M., Gerosa, G., Loubet, B., Altimir, N., Gruenhage, L., Ammann, C., Cieslik, S., Paoletti, E., Mikkelsen, T. N., Ro-Poulsen, H., Cellier, P., Cape, J. N., Horváth, L., Loreto, F., Niinemets, Ü., Palmer, P. I., Rinne, J., 
Misztal, P., Nemitz, E., Nilsson, D., Pryor, S., Gallagher, M. W., Vesala, T., Skiba, U., Brüggemann, N., Zechmeister-Boltenstern, S., Williams, J., O’Dowd, C., Facchini, M. C., de Leeuw, G., Flossman, A., Chaumerliac, N., and Erisman, J. W.: Atmospheric composition change: Ecosystems-Atmosphere interactions, Atmos. Environ., 43, 5193-5267, 2009.

Friedlingstein, P., Cox, P., Betts, R., Bopp, L., Von Bloh, W., Brovkin, V., Cadule, P., Doney, S., Eby, M., Fung, I., Bala, G., John, J., Jones, C., Joos, F., Kato, T., Kawamiya, M., Knorr, W., Lindsay, K., Matthews, H. D., Raddatz, T., Rayner, P., Reick, C., Roeckner, E., Schnitzler, K. G., Schnur, R., Strassmann, K., Weaver, A. J., Yoshikawa, C., and Zeng, N.: Climate-carbon cycle feedback analysis: Results from the $\mathrm{C}^{4} \mathrm{MIP}$ model intercomparison, J. Climate, 19, 3337-3353, 2006.

Guo, L. B. and Gifford, R. M.: Soil carbon stocks and land use change: a meta analysis, Glob. Change Biol., 8, 345-360, 2002.

Hickler, T., Rammig, A., and Werner, C.: Modelling $\mathrm{CO}_{2}$ impacts on forest productivity, Curr. Forestry Rep., 1, 69-80, 2015.

Hoornweg, D. and Bhada-Tata, P.: What a Waste, A Global Review of Solid Waste Management, Urban Development Series Knowledge Papers, March 2012, No. 15. The World Bank, Washington D.C., 98 pp., 2012.

Huntzinger, D. N., Michalak, A. M., Schwalm, C., Ciais, P., King, A. W., Fang, Y., Schaefer, K., Wei, Y., Cook, R. B., Fisher, J. B., Hayes, D., Huang, M., Ito, A., Jain, A. K., Lei, H., Lu, C., Maignan, F., Mao, J., Parazoo, N., Peng, S., Poulter, B., Ricciuto, D., Shi, X., Tian, H., Wang, W., Zeng, N., and Zhao, F.: Uncertainty in the response of terrestrial carbon sink to environmental drivers undermines carbon-climate feedback predictions, Sci. Rep. 7, 4765, https://doi.org/10.1038/s41598-017-03818-2, 2017.

Huxham, M., Whitlock, D., Githaiga, M., and Dencer-Brown, A.: Carbon in the coastal seascape: how interactions between mangrove forests, seagrass meadows and tidal marshes influence carbon storage, Curr. Forestry Rep., 4, 101-110, 2018.

IPCC: 2006 IPCC Guidelines for National Greenhouse Gas Inventories, Prepared by the National Greenhouse Gas Inventories Programme, edited by: Eggleston, H. S., Buendia, L., Miwa, K., Ngara, T., and Tanabe, K., IGES, Japan, 2006.

IPCC: Section 2.8, Harvested Wood Products, in: 2013 Revised Supplementary Methods and Good Practice Guidance Arising from the Kyoto Protocol, edited by: Hiraishi, T., Krug, T., Tanabe, K., Srivastava, N., Baasansuren, J., Fukuda, M., and Troxler, T. G., IPCC, Switzerland, 2014.

Jacob, D. J., Field, B. D., Li, Q., Blake, D. R., de Gouw, J., Warneke, C., Hansel, A., Wisthaler, A., Singh, H. B., and Guenther, A: Global budget of methanol: Constraints from atmospheric observations, J. Geophys. Res., 110, D08303, https://doi.org/10.1029/2004JD005172, 2005.

Jacobson, A. R., Mikaloff Fletcher, S. E., Gruber, N., Sarmiento, J. L., and Gloor, M.: A joint atmosphere-ocean inversion for surface fluxes of carbon dioxide: 1. Methods and global-scale fluxes, Global Biogeochem. Cy., 21, GB1019, https://doi.org/10.1029/2005GB002556, 2007.

Jones, C., Robertson, E., Arora, V., Friedlingstein, P., Shevliakova, E., Bopp, L., Brovkin, V., Hajima, T., Kato, E., Kawamiya, M., Liddicoat, S., Lindsay, K., Reick, C. H., Roelandt, C., Segschneider, J., and Tjiputra, J.: Twenty-first-century compatible $\mathrm{CO}_{2}$ emissions and airborne fraction simulated by CMIP5 earth sys- tem models under four Representative Concentration Pathways, J. Climate, 26, 4398-4413, 2013.

Kayo, C., Oka, H., Hashimoto, S., Mizukami, M., and Takagi, S.: Socioeconomic development and wood consumption, J. For. Res., 20, 309-320, 2015.

Kim, D.-G. and Kirschbaum, M. U. F.: The effect of land-use change on the net exchange rates of greenhouse gases: a compilation of prior estimates, Agric. Ecosyst. Environ., 208, 114-126, 2015.

Kirschbaum, M. U. F.: Will changes in soil organic matter act as a positive or negative feedback on global warming?, Biogeochemistry, 48, 21-51, 2000.

Kirschbaum, M. U. F., Medlyn, B. E., King, D. A., Pongracic, S., Murty, D., Keith, H., Khanna, P. K., Snowdon, P., and Raison, J. R.: Modelling forest-growth response to increasing $\mathrm{CO}_{2}$ concentration in relation to various factors affecting nutrient supply, Global Change Biol., 4, 23-42, 1998.

Kirschbaum, M. U. F., Zeng, G., Ximenes, F., Giltrap, D. L., and Zeldis, J. R.: Towards a more complete quantification of the global carbon cycle, data set, https://doi.org/10.5281/zenodo.2556996, 2019.

Kirschke, S., Bousquet, P., Ciais, P., Saunois, M., Canadell, J. G., Dlugokencky, E. J., Bergamaschi, P., Bergmann, D., Blake, D. R., Bruhwiler, L., Cameron-Smith, P., Castaldi, S., Chevallier, F., Feng, L., Fraser, A., Heimann, M., Hodson, E. L., Houweling, S., Josse, B., Fraser, P. J., Krummel, P. B., Lamarque, J. F., Langenfelds, R. L., Le Quéré, C., Naik, V., O’Doherty, S., Palmer, P. I., Pison, I., Plummer, D., Poulter, B., Prinn, R. G., Rigby, M., Ringeval, B., Santini, M., Schmidt, M., Shindell, D. T., Simpson, I. J., Spahni, R., Steele, L. P., Strode, S. A., Sudo, K., Szopa, S., van der Werf, G. R., Voulgarakis, A., van Weele, M., Weiss, R. F., Williams, J. E., and Zeng, G.: Three decades of global methane sources and sinks, Nat. Geosci., 6, 813-823, 2013.

Kuhlbusch, T. A. J. and Crutzen, P. J.: Toward a global estimate of black carbon in residues of vegetation fires representing a sink of atmospheric, Global Biogeochem. Cy., 9, 491-501, 1995.

Kurz, W. A. and Apps, M. J.: A 70-year retrospective analysis of carbon fluxes in the Canadian forest sector, Ecol. Appl., 9, 526547, 1999.

Lauk, C., Haberl, H., Erb, K. H., Gingrich, S., and Krausmann, F.: Global socioeconomic carbon stocks in longlived products 1900-2008, Environ. Res. Lett., 7, 034023, https://doi.org/10.1088/1748-9326/7/3/034023, 2012.

LeBauer, D. S. and Treseder, K. K.: Nitrogen limitation of net primary productivity in terrestrial ecosystems is globally distributed, Ecology, 89, 371-379, 2008.

Le Quéré, C., Andrew, R. M., Canadell, J. G., Sitch, S., Korsbakken, J. I., Peters, G. P., Manning, A. C., Boden, T. A., Tans, P. P., Houghton, R. A., Keeling, R. F., Alin, S., Andrews, O. D., Anthoni, P., Barbero, L., Bopp, L., Chevallier, F., Chini, L. P., Ciais, P., Currie, K., Delire, C., Doney, S. C., Friedlingstein, P., Gkritzalis, T., Harris, I., Hauck, J., Haverd, V., Hoppema, M., Klein Goldewijk, K., Jain, A. K., Kato, E., Körtzinger, A., Landschützer, P., Lefèvre, N., Lenton, A., Lienert, S., Lombardozzi, D., Melton, J. R., Metzl, N., Millero, F., Monteiro, P. M. S., Munro, D. R., Nabel, J. E. M. S., Nakaoka, S.-I., O’Brien, K., Olsen, A., Omar, A. M., Ono, T., Pierrot, D., Poulter, B., Rödenbeck, C., Salisbury, J., Schuster, U., Schwinger, J., Séférian, R., Skjelvan, I., Stocker, B. D., Sutton, A. J., Takahashi, T., Tian, 
H., Tilbrook, B., van der Laan-Luijkx, I. T., van der Werf, G. R., Viovy, N., Walker, A. P., Wiltshire, A. J., and Zaehle, S.: Global Carbon Budget 2016, Earth Syst. Sci. Data, 8, 605-649, https://doi.org/10.5194/essd-8-605-2016, 2016.

Le Quéré, C., Andrew, R. M., Friedlingstein, P., Sitch, S., Pongratz, J., Manning, A. C., Korsbakken, J. I., Peters, G. P., Canadell, J. G., Jackson, R. B., Boden, T. A., Tans, P. P., Andrews, O. D., Arora, V. K., Bakker, D. C. E., Barbero, L., Becker, M., Betts, R. A., Bopp, L., Chevallier, F., Chini, L. P., Ciais, P., Cosca, C. E., Cross, J., Currie, K., Gasser, T., Harris, I., Hauck, J., Haverd, V., Houghton, R. A., Hunt, C. W., Hurtt, G., Ilyina, T., Jain, A. K., Kato, E., Kautz, M., Keeling, R. F., Klein Goldewijk, K., Körtzinger, A., Landschützer, P., Lefèvre, N., Lenton, A., Lienert, S., Lima, I., Lombardozzi, D., Metzl, N., Millero, F., Monteiro, P. M. S., Munro, D. R., Nabel, J. E. M. S., Nakaoka, S.-I., Nojiri, Y., Padin, X. A., Peregon, A., Pfeil, B., Pierrot, D., Poulter, B., Rehder, G., Reimer, J., Rödenbeck, C., Schwinger, J., Séférian, R., Skjelvan, I., Stocker, B. D., Tian, H., Tilbrook, B., Tubiello, F. N., van der Laan-Luijkx, I. T., van der Werf, G. R., van Heuven, S., Viovy, N., Vuichard, N., Walker, A. P., Watson, A. J., Wiltshire, A. J., Zaehle, S., and Zhu, D.: Global Carbon Budget 2017, Earth Syst. Sci. Data, 10, 405-448, https://doi.org/10.5194/essd-10-405-2018, 2018.

Mahowald, N. M., Baker, A. R., Bergametti, G., Brooks, N., Duce, R. A., Jickells, T. D., Kubilay, N., Prospero, J. M., and Tegen, I: Atmospheric global dust cycle and iron inputs to the ocean, Global Biogeochem. Cy., 19, GB4025, https://doi.org/10.1029/2004GB002402, 2005.

Marland, G. and Rotty, R. M.: Carbon dioxide emissions from fossil fuels: a procedure for estimation and results for 1950-1982, Tellus B, 36, 232-261, 1984.

McLeod, E., Chmura, G. L., Bouillon, S., Salm, R., Bjork, M., Duarte, C. M., Lovelock, C. E., Schlesinger, W. H., and Silliman, B. R.: A blueprint for blue carbon: toward an improved understanding of the role of vegetated coastal habitats in sequestering $\mathrm{CO}_{2}$, Front. Ecol. Environ., 9, 552-560, 2011.

Mendonca, R., Muller, R. A., Clow, D., Verpoorter, C., Raymond, P., Tranvik, L. J., and Sobek, S.: Organic carbon burial in global lakes and reservoirs, Nat. Commun., 8, 1694, https://doi.org/10.1038/s41467-017-01789-6, 2017.

Minasny, B., Malone, B. P., McBratney, A. B., Angers, D. A., Arrouays, D., Chambers, A., Chaplot, V., Chen, Z. S., Cheng, K., Das, B. S., Field, D. J., Gimona, A., Hedley, C. B., Hong, S. Y., Mandal, B., Marchant, B. P., Martin, M., McConkey, B. G., Mulder, V. L., O'Rourke, S., Richer-de-Forges, A. C., Odeh, I., Padarian, J., Paustian, K., Pan, G. X., Poggio, L., Savin, I., Stolbovoy, V., Stockmann, U., Sulaeman, Y., Tsui, C. C., Vågen, T. G., van Wesemael, B., and Winowiecki, L.: Soil carbon 4 per mille, Geoderma, 292, 59-86, 2017.

Norby, R. J., Warren, J. M., Iversen, C. M., Medlyn, B. E., and McMurtrie, R. E.: $\mathrm{CO}_{2}$ enhancement of forest productivity constrained by limited nitrogen availability, Proc. Natl. Acad. Sci. USA, 107, 19368-19373, 2010.

Pan, Y. D., Birdsey, R. A., Fang, J. Y., Houghton, R., Kauppi, P. E., Kurz, W. A., Phillips, O. L., Shvidenko, A., Lewis, S. L., Canadell, J. G., Ciais, P., Jackson, R. B., Pacala, S. W., McGuire, A. D., Piao, S. L., Rautiainen, A., Sitch, S., and Hayes, D.: A large and persistent carbon sink in the World's forests, Science, 333, 988-993, 2011.
Paulot, F., Crounse, J. D., Kjaergaard, H. G., Kurten, A., St Clair, J. M., Seinfeld, J. H., and Wennberg, P. O.: Unexpected epoxide formation in the gas-phase photooxidation of isoprene, Science, 325, 730-733, 2009.

Prognos: European Atlas of Secondary Raw Materials, 2004 Status Quo and Potentials, Prognos AG, Basel, Switzerland, a.o., 17 pp., 2008.

Pugh, T. A. M., Muller, C., Arneth, A., Haverd, V., and Smith, B.: Key knowledge and data gaps in modelling the influence of $\mathrm{CO}_{2}$ concentration on the terrestrial carbon sink, J. Plant Physiol., 203, 3-15, 2016.

Pendleton, L., Donato, D. C., Murray, B. C., Crooks, S., Jenkins, W. A., Sifleet, S., Craft, C., Fourqurean, J. W., Kauffman, J. B., Marba, N., Megonigal, P., Pidgeon, E., Herr, D., Gordon, D., and Baldera, A.: Estimating global "Blue Carbon" emissions from conversion and degradation of vegetated coastal ecosystems, PLOS One, 7, e43542, https://doi.org/10.1371/journal.pone.0043542, 2012.

Quinton, J. N., Govers, G., Van Oost, K., and Bardgett, R. D.: The impact of agricultural soil erosion on biogeochemical cycling, Nat. Geosci., 3, 311-314, 2010.

Raymond, P. A., Hartmann, J., Lauerwald, R., Sobek, S., McDonald, C., Hoover, M., Butman, D., Striegl, R., Mayorga, E., Humborg, C., Kortelainen, P., Durr, H., Meybeck, M., Ciais, P., and Guth, P.: Global carbon dioxide emissions from inland waters, Nature, 503, 355-359, 2013.

Regnier, P., Friedlingstein, P., Ciais, P., Mackenzie, F. T., Gruber, N., Janssens, I. A., Laruelle, G. G., Lauerwald, R., Luyssaert, S., Andersson, A. J., Arndt, S., Arnosti, C., Borges, A. V., Dale, A. W., Gallego-Sala, A., Godderis, Y., Goossens, N., Hartmann, J., Heinze, C., Ilyina, T., Joos, F., LaRowe, D. E., Leifeld, J., Meysman, F. J. R., Munhoven, G., Raymond, P. A., Spahni, R., Suntharalingam, P., and Thullner, M.: Anthropogenic perturbation of the carbon fluxes from land to ocean, Nat. Geosci., 6, 597-607, 2013.

Reyer, C.: Forest productivity under environmental change: A review of stand-scale modeling studies, Curr. Forestry Rep., 1, 53$68,2015$.

Richey, J. E.: Pathways of atmospheric $\mathrm{CO}_{2}$ through fluvial systems, in: The global carbon cycle, edited by: Field, C. B. and Raupach, M. R., Integrating humans, climate, and the natural world, Scope 62, Island Press, Washington, 329-340, 2004.

Romankevich, E. A.: Geochemistry of Organic Matter in the Ocean, Springer, Berlin, 334 pp., 1984.

Romankevich, E. A., Vetrov, A. A., and Peresypkin, V. I.: Organic matter of the World Ocean, Russ. Geol. Geophys., 50, 299-307, 2009.

Ryan, M. G., Binkley, D., and Fownes, J. H.: Age-related decline in forest productivity: Pattern and process, Adv. Ecol. Res., 27, 213-262, 1997.

Schipper, L. A., Mudge, P. L., Kirschbaum, M. U. F., Hedley, C. B., Golubiewski, N. E., Smaill, S. J., and Kelliher, F. M.: A review of soil carbon change in grazed New Zealand pastures, N. Z. J. Agric. Res., 60, 93-118, 2017.

Schlünz, B. and Schneider, R. R.: Transport of terrestrial organic carbon to the oceans by rivers: re-estimating flux- and burial rates, Int. J. Earth Sci., 88, 599-606, 2000.

Seitzinger, S. P., Harrison, J. A., Dumont, E., Beusen, A. H. W., and Bouwman, A. F.: Sources and delivery of carbon, 
nitrogen, and phosphorus to the coastal zone: An overview of Global Nutrient Export from Watersheds (NEWS) models and their application, Global Biogeochem. Cy., 19, GB4S01, https://doi.org/10.1029/2005GB002606, 2005.

Sitch, S., Friedlingstein, P., Gruber, N., Jones, S. D., MurrayTortarolo, G., Ahlström, A., Doney, S. C., Graven, H., Heinze, C., Huntingford, C., Levis, S., Levy, P. E., Lomas, M., Poulter, B., Viovy, N., Zaehle, S., Zeng, N., Arneth, A., Bonan, G., Bopp, L., Canadell, J. G., Chevallier, F., Ciais, P., Ellis, R., Gloor, M., Peylin, P., Piao, S. L., Le Quéré, C., Smith, B., Zhu, Z., and Myneni, R.: Recent trends and drivers of regional sources and sinks of carbon dioxide, Biogeosciences, 12, 653679, https://doi.org/10.5194/bg-12-653-2015, 2015.

Stallard, R. F.: Terrestrial sedimentation and the carbon cycle: Coupling weathering and erosion to carbon burial, Global Biogeochem. Cy., 12, 231-257, 1998.

Stinson, G., Kurz, W. A., Smyth, C. E., Neilson, E. T., Dymond, C. C., Metsaranta, J. M., Boisvenue, C., Rampley, G. J., Li, Q., White, T. M., and Blain, D.: An inventory-based analysis of Canada's managed forest carbon dynamics, 1990 to 2008, Glob. Change Biol., 17, 2227-2244, 2011.

Tranvik, L. J., Downing, J. A., Cotner, J. B., Loiselle, S. A., Striegl, R. G., Ballatore, T. J., Dillon, P., Finlay, K., Fortino, K., Knoll, L. B., Kortelainen, P. L., Kutser, T., Larsen, S., Laurion, I., Leech, D. M., McCallister, S. L., McKnight, D. M., Melack, J. M., Overholt, E., Porter, J. A., Prairie, Y., Renwick, W. H., Roland, F., Sherman, B. S., Schindler, D. W., Sobek, S., Tremblay, A., Vanni, M. J., Verschoor, A. M., von Wachenfeldt, E., and Weyhenmeyer, G. A.: Lakes and reservoirs as regulators of carbon cycling and climate, Limnol. Oceanogr., 54, 2298-2314, 2009.

Van Oost, K., Quine, T. A., Govers, G., De Gryze, S., Six, J., Harden, J. W., Ritchie, J. C., McCarty, G. W., Heckrath, G., Kosmas, C., Giraldez, J. V., da Silva, J. R. M., and Merckx, R.: The impact of agricultural soil erosion on the global carbon cycle, Science, 318, 626-629, 2007.

Wang, X., Padgett, J. M., De la Cruz, F. B., and Barlaz, M. A.: Wood biodegradation in laboratory scale landfills, Environ. Sci. Technol., 45, 6864-6871, 2011.
Wang, X., De la Cruz, F. B., Ximenes, F., Barlaz, M. A.: Decomposition and carbon storage of selected paper products in laboratory-scale landfills, Sci. Total Environ., 532, 70-79, 2015.

Ward, N. D., Bianchi, T. S., Medeiros, P. M., Seidel, M., Richey, J. E., Keil, R. G., and Sawakuchi, H. O.: Where carbon goes when water flows: carbon cycling across the aquatic continuum, Front. Mar. Sci., 4, 7, https://doi.org/10.3389/fmars.2017.00007, 2017.

Webb, N. P., Chappell, A, Strong, C. L., Marx, S. K., and McTainsh, G. H.: The significance of carbon-enriched dust for global carbon accounting, Glob. Change Biol., 18, 3275-3278, 2012.

Winjum, J. K., Brown, S., and Schlamadinger, B.: Forest harvests and wood products: sources and sinks of atmospheric carbon dioxide, Forest Sci., 44, 272-284, 1998.

Xi, F. M., Davis, S. J., Ciais, P., Crawford-Brown, D., Guan, D. B., Pade, C., Shi, T. M., Syddall, M., Lv, J., Ji, L. Z., Bing, L. F., Wang, J. Y., Wei, W., Yang, K. H., Lagerblad, B., Galan, I., Andrade, C., Zhang, Y., and Liu, Z.: Substantial global carbon uptake by cement carbonation, Nat. Geosci., 9, 880-883, 2016.

Ximenes, F., Bjordal, C., Cowie, A., and Barlaz, M.: The decay of wood in landfills in contrasting climates in Australia, Waste Manage., 41, 101-110, 2015.

Ximenes, F., Cowie, A., and Barlaz, M.: The decay of engineered wood products and paper excavated from landfills in Australia, Waste Manage., 74, 312-322, 2018.

Ximenes, F. A., Björdal, C., Kathuria, A., Barlaz, M. A. and Cowie, A. L.: Improving understanding of carbon storage in wood in landfills: Evidence from reactor studies, Waste Manage., 85, 341-350, 2019.

Yang, D. W., Kanae, S., Oki, T., Koike, T., and Musiake, K.: Global potential soil erosion with reference to land use and climate changes, Hydrol. Process., 17, 2913-2928, 2003.

Zender, C. S., Bian, H., and Newman, D.: Mineral dust entrainment and deposition (DEAD) model: description and 1990s dust climatology, J. Geophys. Res., 108, 4416, https://doi.org/10.1029/2002JD002775, 2003. 